DOI: https://doi.org/10.24144/2409-6857.2018.2(52).124-129

УДК 334.02

\author{
Огородник В.О., Фіалковський А.Р., Жорж Л.В., Біла Н.Я.
}

\title{
СТРАТЕГІЧНИЙ КОНТРОЛІНГ ЕФЕКТИВНОСТІ
}

\begin{abstract}
Контролінг запропоновано розглядати як систему стратегічного управління, що спрямована на створення набору інструментів стратегічного аналізу, формування адекватної вимогам розвитку інформаційної бази, які в сукупності забезпечують менеджмент обтрунтованими ріменнями та способами їх реалізації. Ефективність виступає одночасно як фінансово-економічна мета розвитку та засіб (фактор), які є необхідними в процесі формування конкурентних переваг. Контролінг ефективності як иілі та фактору розвитку одночасно забезпечує досягнення оптимального балансу між результатами розвитку та ресурсами для його отримання; своєчасну фінансово-економічну координацію рімень, прийнятих відповідно до внутрішнього стану системи та навколишнього світу; узгодженість інтересів економічного розвитку різних акторів та моральної відповідальності за результати; інформаційну базу для прийняття рішень щзодо вектора та імпульсу майбутнього розвитку.
\end{abstract}

Ключові слова: ефективність, економічна система, розвиток, контролінг, стратегічне управління, конкурентні переваги.

Постановка проблеми. Сучасні тренди, що складаються в економічному житті, від посилення глобалізації до четвертої промислової революції, створюють для бізнесу, регіону, країни в цілому нові можливості й виклики одночасно. Для уникнення небезпек та реалізації можливостей вельми актуальним для господарюючих систем всіх рівнів в процесі стратегічного управління ними стає посилення уваги до питань результативності. Саме результативність дозволяє оцінити в процесі довгострокового управління правильність або помилковість обраної мети, стратегії та тактики іï реалізації. Результативність економічної діяльності може знаходити прояв як у стратегічному фіаско, так й у нових конкурентних перевагах.

Змістовною фінансово-економічною ознакою результативності $\epsilon$ ефективність.

Ефективність має широкий діапазон застосування, представляючи собою як економічну категорію, так й інструмент, за допомогою якого здійснюється аналіз фінансових результатів діяльності та відбувається планування поточного стану або майбутніх перспектив.

(C) Огородник В.О., к.е.н., доц., доцент кафедри фінансів і банківської справи ДВНЗ «Ужгородський національний університет», e-mail: valeriya.ohorodnyk@uzhnu.edu.ua

Фіалковський А.P., аспірант кафедри економіки i підприємництва ДВНЗ «Ужгородський національний університет», м. Ужгород e-mail: Andrey.Fialkovsky@progresstech.aero

Жорж Л.В.,студентка магістерської програми ДВНЗ «Ужгородський національний університет», м. Ужгород, e-mail: Zorhz.10@gmail.com

Біла Н.Я ,студентка магістерської програми ДВНЗ «Ужгородський національний університет», м. Ужгород, , e-mail: Nadyshka2911@gmail.com
Ефективність слугує оцінці не лише економічної або фінансової діяльності, але й системи управління в цілому та її елементів. Лише при узгодженій взаємодії компонентів система управління забезпечує відповідний результат

функціонування бізнесу, регіону чи національної економіки в цілому.

Відстеження ефективності вимагає застосування сучасних інструментів стратегічного управління, серед яких найбільш дієвим $є$ контролінг.

Контролінг, представляючи принципово нове явище в історії управління, яке появилося у другій половині минулого століття, має сьогодні високу ходу застосування як на мікро, так й на макрорівнях.

Сучасна практика стратегічного управління слугує підтвердженням широких можливостей контролінгу, особливо у сфері спостереження ефективності економічної та фінансової активності господарюючих систем.

Аналіз останніх досліджень і публікацій. Відносна новизна стратегічної функції та механізму контролінгу обумовила поліваріантність підходів до його визначення. Так, Брохун Н. систематизувала сучасні підходи наступним чином: «Отже, більшість вчених -27 $\%$ схиляються до думки, що "контролінг" система управління, що включає аналіз, управлінський облік, внутрішньогосподарський контроль. 18 \% науковців розглядає “контролінг”, як концепцію управління та як контроль за рівнем доходів і витрат. Що "контролінг" - це елемент управління вважає $14 \%$ науковців. На ознаки процес управління та синтетична дисципліна, що включає менеджмент, маркетинг, планування, облік і контроль припадає по 9 \%, 5 \% науковців 
вважає, що контролінг - це реалізація фінансовоекономічної функції.» [2]

3 позиції механіцизму розглядає сутність контролінгу Васильєв П.В., вважаючи, що «поняття механізму стратегічного контролінгу це комплексна, автономна, система, що самоорганізується, інформаційно-аналітичної підтримки керівного органу підприємства в процесі здійснення стратегічного управління, що складається 3 елементів контролінгу взаємозалежно функціонуючих в формалізованої послідовності». [3] При цьому завуальованим залишається відмінність між сутністю контролінгу і його механізмом.

Мошак С.М. та його однодумці вважають доцільним розглядати ефективність та пї контролінг як важливі складові стратегічного управління, що забезпечують конкурентоспроможність економічної системи. Але логіка дослідження не охоплює реальні важелі стратегічного контролінгу, спрямовані на підвищення ефективності [8].

Функціональний підхід до сутності контролінгу охоплює коло дій стратегічного спрямування, які відстежують реалізацію стратегій. Мікловда В.П., Кубіній Н.Ю. висувають ідею необхідності рефреймінгу економічних систем на засадах контролінгу: «Сучасні умови діяльності підприємств викликають доцільність їх реструктуризації на основі впровадження та розширення сфери функції контролінгу як базової функції стратегічного управління.» [6, с.376]. Вказані автори разом 3 Завадяком P.I. доводять, що контролінг в умовах корпоративного ведення справи $\epsilon$ умовою забезпечення конкурентоспроможності [8, с.100-102], [4]. Але вказані дослідники не охопили ланцюг залежності ефективності економічної діяльності від функціонального навантаження контролінгу ділової активності.

Розглядаючи сутність контролінгу Зайцева А.М. і Попова А.В. підходять 3 фінансових позицій, включаючи в предмет контролінгу витрати, при цьому вважаючи, що «стратегічне управління витратами передбачає управління витратами, які характеризуються високим динамізмом, вагою вимірювання, обліку. Основні завдання цієї системи: управління витратами для підвищення продуктивності підприємства; проведення розрахунку необхідної кількості витрат на товари, роботи; правильне визначення виробничих витрат; визначення основних способів і засобів вимірювання, контролю та обліку витрат» [5, с.93]. Аналогічні думки висловлює Федулова Л.І. [9] Однак, автори залишають поза увагою той факт, що витрати в даному контексті без ув'язки 3 результатами представляють категорію поточного аналізу, особливо в області обліку.

Як слідує з огляду публікацій, проблематика контролінгу саме ефективності достатньою мірою не охоплена науковими дослідженнями.

Формулювання цілей статті. Метою даної роботи $\epsilon$ визначення сутності та змісту контролінгу ефективності діяльності підприємства як категорії та методичного інструменту управління господарською діяльністю.

Для досягнення мети вирішені завдання:

1. Визначена сутність та значення контролінгу в сучасних умовах функціонування економічних систем.

2. Показана категоріальна та методична сутність ефективності.

3. Висвітлена взаємодія змістовних складових ефективності в процесі її контролігну.

В ході дослідження були застосовані таки методи як наукова абстракція при окресленні складових ефективності, узагальнення - в процесі огляду сучасних наукових позицій, формалізації - при окресленні сили імпульсу ефективності як фактору розвитку і т.д.

Опис основного матеріалу дослідження. Контролінг як механізм стратегічного управління становить собою симбіоз функцій управління, спрямованих на спостереження за реалізацією стратегічних планів розвитку економічної системи. Контролінг на практиці включає поєднання аналізу і планування, які в сукупності дозволяють розкрити ретроспективу господарської діяльності економічного гравця, а також оцінити можливі варіанти майбутнього розвитку. Широко відомо, що «контролінг - це підсистема стратегічного менеджменту, яка координує функції стратегічного аналізу, визначення мети, планування $\mathrm{i}$ коригування стратегії; контролює роботу всієї системи в цілому і всіх функціональних областей діяльності підприємства, а також задає, розвиває і контролює підсистему стратегічного інформаційного забезпечення» [7]. Саме внаслідок аналізу вже отриманих результатів та сучасного стану координація стратегічних намірів економічної системи являє собою квінтесенцію контролінгу.

Виходячи $з$ цього контролінг ми розглядаємо як систему, яка вирішує наступні завдання:

a) забезпечити менеджмент інструментарієм стратегічного аналізу, результати якого дозволяють сформувати або ж скоригувати стратегічну мету розвитку,

б) запропонувати набір методів стратегічного планування

в) сформувати інформаційну базу 
г) обгрунтувати варіанти прийняття стратегічних управлінських рішень.

Контролінг сприяє реалізації широкого кола функцій стратегічного управління, серед яких виділено наступні:

a) забезпечує реалізацію стратегічних цілей розвитку економічної системи, надаючи інформацію про стан та відхилення від запланованих індикаторів;

б) підвищує темпи реалізації покладених стратегічних завдань;

в) знижує витрати (в тому числі трансакційні), які $\epsilon$ потрібними для виконання договірних зобов'язань в процесі господарської діяльності.

Іншими словами, контролінг в процесі стратегічного управління сприяє вирішенню головної фінансово-економічної мети підвищенню ефективності економічної системи, що в свою чергу надає конкурентні переваги системі в цілому. Отримання конкурентних переваг на основі підвищення ефективності реалізується внаслідок:

- вдосконалення цінової політики, що дозволяє управління ефективністю:

- захоплення нових ринків, які базуються на високо витратних бізнес-процесах;

- можливості впроваджувати нові продукти та технології, які самі по собі представляють інновації та формують конкурентні переваги.

Контролінг в процесі тактичної економічної діяльності дозволяе оцінити сучасний економічний стан господарюючого актора, що сприяє виявленню поточних і перспективних резервів його розвитку.
В умовах четвертої індустріальної революції, яка відбувається на фоні глобалізації, значення контролінгу в цілому істотно зростає внаслідок:

1. Посилення турбулентності зовнішнього середовища, ускладнення економічних відносин, посилення сил на конкурентних полях, які ускладнюються внаслідок захоплення цифровою економікою.

2. Перманентній внутрішніх змін економічних системи, а також їх постійного рефрейминга.

3. Посилення ролі креативної праці в результатах розвитку економічної системи, що не тільки ускладнюе вимір витрат праці, а й викликає необхідність пошуку нових сутнісних підходів до визначення його ефективності.

Контролінг на практиці передбачає дослідження фінансово-економічних аспектів, у складі яких важливе місце належить ефективності. В сучасних умовах, коли четверта промислова революція охопила економіку передових країн і починає активно проявлятися на підприємствах України, кардинально змінюється сутність ефективності, іiі філософський i управлінський зміст.

Ефективність в класичній економіці являє собою співвідношення результатів і витрат, використаних в процесі виробництва продукту.

$\mathrm{y}$ нашому дослідженні ми розглядаємо ефективність у двох іпостасях. Ефективність - це мета функціонування економічного гравця й одночасно засіб, що забезпечує досягнення його мети. Підходи до сутності ефективності показані на рис. 1.

Ефективність як мета являє собою в політ-

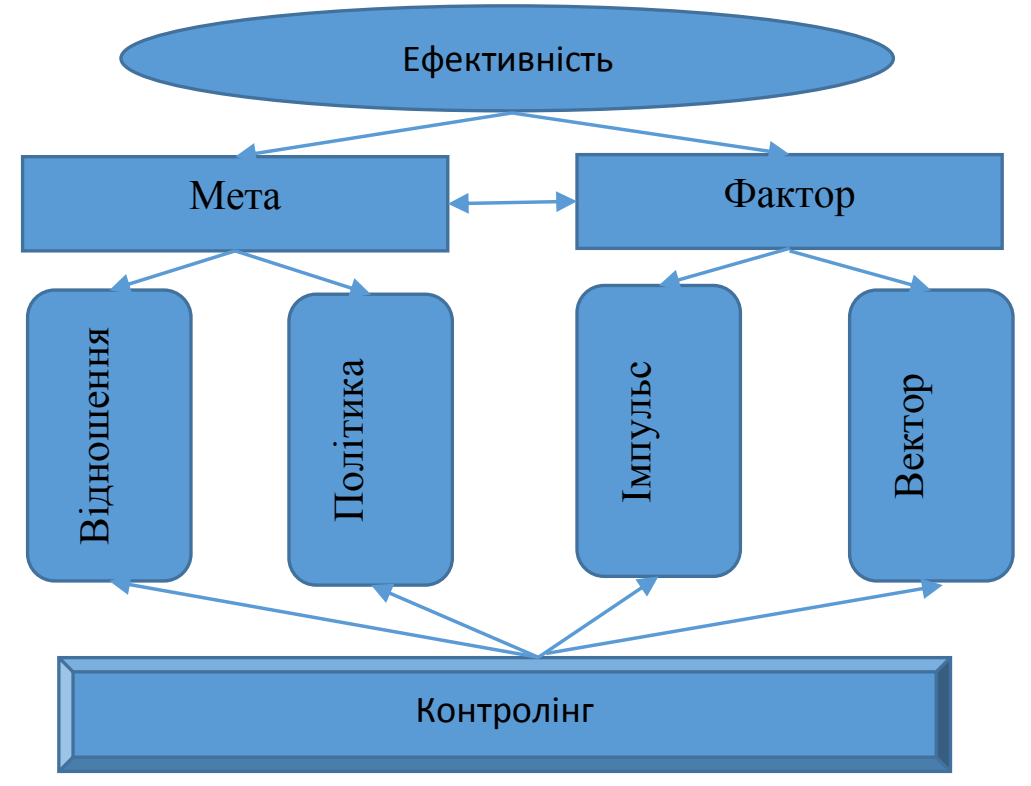

*Джерело: складено авторами

Рис. 1. Ефективність як мета та фактор* 
економічному сенсі квінтесенцію відносин 3 приводу доцільності, корисності виробленого продукту i видів і кількості ресурсів, що витрачаються на дане виробництво і реалізацію. Відносини виникають в першу чергу між виробником i суспільством (3 приводу невідновлюваних ресурсів, навколишнього середовища, розв'язання соціальних проблем і т.д.), а також між керуючою системою і керованої в рамках підприємства. Останні виражаються через собівартість і прибутковість продукції, через залучення певних технологій, через кадрову політику, через ціну робочої сили на підприємстві. Зазначені категорії є не тільки економічними, вони несуть соціальну і моральну навантаження: ресурси суспільства, регіону, підприємства або окремої людини повинні використовуватися таким чином, щоб не наносили шкоди їх власнику, щоб сприяли його розвитку.

У цьому контексті контролінг ефективності представляє функцію стратегічного управління, спрямовану на проведення такої політики ефективності, яка виступає запорукою формування конкурентних стратегічних переваг і моральності їх досягнення.

Політика ефективності, що обрана i контрольована в процесі іiі реалізації, визначає спосіб управління, спонукає прийняття таких ділових рішень, оптимальність і моральність яких має систему соціальних, екологічних, економічних обмежень.

Ефективність як мета спрямована на формування економічних переваг підприємства i забезпечення його кращого позиціонування на ринку. Залежно від ринку, про який йде мова в конкретному випадку, це може бути ефективність виробництва продукції (на ринку товарів), ефективність вкладень (на ринку інвестицій), ефективність праці (на ринку праці) і т.д.

У цьому сенсі стратегічний контролінг являе собою таку підсистему управління, яка відстежує сформовані відносини між підприємством і навколишнім світом з одного боку, а також між управлінням і керованої складовою - 3 іншого. Одночасно стратегічний контролінг спрямований на забезпечення відповідності між метою та політикою економічної системи, взаємодія яких має знаходитися в гармонії.

Як фактор ефективність являє собою силу, імпульс якої служить:

- економії витрат на виробництво продукції;

- збільшення прибутковості, що сприяе утворенню і накопиченню майбутніх інвестицій в розвиток.

Імпульс може служити індикатором розвитку економічної системи. У механіці імпульс визначається як добуток маси на швидкість. Використовуючи даний метод в економіці контролінг може включити у свій арсенал індикаторів імпульс ефективності, який становить твір базового обсягу певного ресурсу (тобто його маси) на темп зростання ефективності.

Ефективність також являє собою:

a) фактор, що забезпечує поточне ціноутворення, яке в свою чергу служить підмогою певного стратегічного становища на ринках;

б) фактор, що показує раціональність i прибутковість поточних i стратегічних інвестицій.

Іншими словами, ефективність як фактор має певну спрямованість, вектор якої показує доцільність певного рішення, що забезпечує той чи інший вибір шляху розвитку. За думкою Батракової, «ефективність - це показник прагнення до кінцевого результату, але не саме результат, а варіант правильності, точність напряму до нього (кінцевого результату)» [1, c.175].

Неможливо не відзначити, що ефективність як мета і як засіб не перебувають в стані супротивності, а виступають як елементи однієї системи, дія якої задано стратегією розвитку бізнесу. Одночасно контролінг, відстежуючи реалізацію мети і дію фактору ефективності, забезпечує:

a) досягнення оптимального співвідношення між результатами розвитку і ресурсами на його отримання;

б) своєчасну економічну координацію вже прийнятих рішень відповідно до внутрішнього стану системи, що функціонує і світу, що іiі оточує;

в) узгодженість економічних інтересів розвитку і моральної відповідальності за його результати;

г) інформаційну базу для прийняття рішень щодо вектора та імпульсу майбутнього розвитку. Впровадження контролінгу ефективності дозволяє економічній системі отримати задані результати у вигляді реальних конкурентних стратегічних переваг.

Висновки i перспективи подальших досліджень. Контролінг - це система стратегічного управління, яка спрямована на створення інструментарію стратегічного аналізу, формування адекватної вимогам розвитку інформаційної бази, які в сукупності забезпечують менеджмент обгрунтованими рішеннями та способами їх реалізації.

Ефективність виступає одночасно як фінансово-економічна мета розвитку та засіб (фактор), які є необхідними в процесі формування 
конкурентних переваг. Ефективність як мета полягає в політичній економіці - квінтесенцію відносин щодо доцільності, корисності продукту та типів і кількості ресурсів, витрачених на це виробництво та продаж. У цьому контексті контролінг ефективності є функцією стратегічного управління, спрямованої на реалізацію такої політики ефективності, яка $\epsilon$ ключем до формування конкурентоспроможних стратегічних переваг та моральності їх досягнення.

Ефективність $є$ фактором, що забезпечує поточне ціноутворення, яке в свою чергу слугує підтримкою певної стратегічної позиції на ринках, а також чинником, який показує раціональність та прибутковість поточних та стратегічних інвестицій.
Контролінг ефективності як цілі та фактору розвитку одночасно забезпечує:

a) досягнення оптимального балансу між результатами розвитку та ресурсами для його отримання;

б) своєчасну фінансово-економічну координацію рішень, прийнятих відповідно до внутрішнього стану системи та навколишнього світу;

б) узгодженість інтересів економічного розвитку різних акторів та моральної відповідальності за результати;

в) інформаційну базу для прийняття рішень щодо вектора та імпульсу майбутнього розвитку.

В подальшому дослідженні заплановано розробити інструментарій оцінки ефективності діяльності економічних систем в процесі стратегічного управління їх розвитком.

\section{ПЕРЕЛІК ВИКОРИСТАНИХ ДЖЕРЕЛ}

1. Батракова Т. І. Сутність поняття «економічна ефективність діяльності підприємств» в ринкових умовах / Т. І. Батракова. // Науковий вісник Полтавського університету економіки і торгівлі. - 2015. - №1. (69), ч. 1. - С. 172-178.

2. Брохун Н. С. Що таке контролінг? / Н. С. Брохун. // Вісник Житомирського державного технологічного університету. Серія: економіка, управління та адміністрування. - 2007. - №4(42). - С. 32-47.

3. Васильев П. В. Механизм стратегического контролинга в управлении конкурентоспособностью предприятия [Електронний ресурс] / П. В. Васильев // Современные исследования социальных проблем (электронный научный журнал).. - 2014. - Режим доступу до pecypcy: https://cyberleninka.ru/article/v/mehanizmstrategicheskogo-kontrollinga-v-upravlenii-konkurentosposobnostyu-predpriyatiya.

4. Ефективність управління підприємствами: сучасні проблеми та перспективи їх вирішення: Монографія / Мікловда В.П., Брітченко І.Г., Кубіній Н.Ю., Дідович Ю.О. - Полтава: ПУЕТ, 2013. - 218 с.

5. Зайцева, А. М. Методы и инструменты стратегического контроллинга в системе управления предприятием / А. М. Зайцева, А. В. Попова // Инновационные перспективы Донбасса: материалы международной научнопрактической конференции, г. Донецк, 20-22 мая 2015 г. Т. 6 : Актуальные проблемы инновационного развития экономики Донбасса / М-во образования и науки ДНР и др.; редкол.: Л.П. Полякова и др. - Донецк : ГВУЗ "ДонНТУ", 2015. - С. 89-94.

6. Конкурентоспроможність економічних систем та стратегічне управління нею: гносеологічний та утилітарний ракурси: монографія / В.П. Мікловда, Ф.Ф. Шандор, Н.Ю. Кубіній, С.М. Мошак, Ю.О. Дідович, В.О. Огородник, Я.С. Максимчук, В.В. Кубіній. - Мукачево: Карпатська вежа. - 2015. - 420 с.

7. Лаенко О.А. Стратегический контроллинг / О.А. Лаенко, К.Е. Денисова // Международный журнал социальных и гуманитарных наук. - 2016. -№1. Т. 6. - С. 232-236.

8. Стратегічне управління конкурентоспроможністю: системний метода та екзистенціальна експозиція: монографія / Мошак С.М., Мікловда В.П., Кубіній Н.Ю. та ін. - Мукачево: Карпатська вежа. - 2017 - 240 с.

9. Стратегічне управління ефективністю підприємств у корпоративному секторі регіону: проблеми та шляхи вдосконалення: Монографія / В.В. Мікловда, Н.Ю. Кубіній, Р.І. Завадяк та ін. - Ужгород: Ліра, 2010. - 196 с.

10. Федулова Л.І. Актуальні проблеми менеджменту в країні / Л. Федулова. - К.: Фенікс, 2005. - 320 с.

\section{REFERENCES}

1. Batrakova, T.I. (2015). Sutnist' ponyattya «ekonomichna efektyvnist' diyal'nosti pidpryyemstv» v rynkovykh umovakh [The concept essence of «enterprises economic efficiency» in market conditions] Naukovyy visnyk Poltavs'koho universytetu ekonomiky i torhivli. Scientific Bulletin of the Poltava University of Economics and Trade, 1, 172-178 [in Ukrainian]

2. Brokhun, N.S. (2007). Shcho take kontrolinh? [What is Controlling?] Visnyk Zhytomyrs'koho derzhavnoho tekhnolohichnoho universytetu. Seriya: ekonomika, upravlinnya ta administruvannya. Bulletin of the Zhytomyr State Technological University. Series: Economics, Management and Administration, 4(42), 32-47 [in Ukrainian]

3. Vasyl'ev, P.V. (2014). Mekhanyzm stratehycheskoho kontrolynha v upravlenyy konkurentosposobnost'yu predpryyatyya [Mechanism of strategic control in managing the competitiveness of the enterprise] Sovremennye yssledovanyya sotsyal'nykh problem. Modern researches of social problems. Retrieved from: https://cyberleninka.ru/article/v/mehanizm-strategicheskogo-kontrollinga-v-upravlenii-konkurentosposobnostyupredpriyatiya. [in Russian] 
4. Miklovda, V.P., Britchenko, I.H., Kubiniy, N.YU., Didovych, Yu.O (2013). Efektyvnist' upravlinnya pidpryyemstvamy: suchasni problemy ta perspektyvy yikh vyrishennya [E nterprise management efficiency: current problems and perspectives for their solution] - Poltava: PUET [in Ukrainian]

5. Zaytseva, A. M. (2015). Metody y ynstrumenty stratehycheskoho kontrollynha v systeme upravlenyya predpryyatyem [Methods and tools of strategic control in the enterprise management system] Proceedings from Mezhdunarodnoy nauchno-praktycheskoy konferentsyy «Aktual'nye problemy ynnovatsyonnoho razvytyya ékonomyky Donbassa» - International scientific and practical conference «Actual problems of innovative development of the Donbass economy». (pp.89-94). Donetsk : HVUZ "DonNTU" [in Russian]

6. Miklovda, V.P., Shandor, F.F., Kubiniy, N.Yu., Moshak, S.M., Didovych, Yu.O., Ohorodnyk, V.O., Maksymchuk, Ya.S., Kubiniy, V.V. (2015) Konkurentospromozhnist' ekonomichnykh system ta stratehichne upravlinnya neyu: hnoseolohichnyy ta utylitarnyy rakursy [Competitiveness of economic systems and its strategic management: epistemological and utilitarian perspectives]- Mukachevo: Karpat·s'ka vezha. [in Ukrainian]

7. Laenko, O.A., Denysova, K.E. (2016). Stratehycheskyy kontrollynh [Strategic Controlling] Mezhdunarodnyy zhurnal sotsyal'nykh y humanytarnykh nauk. International Journal of Social and Human Sciences, 1. T.6. 232-236. [in Russian]

8. Moshak, S.M., Miklovda, V.P., Kubiniy, N.Yu, et al. (2017). Stratehichne upravlinnya konkurentospromozhnistyu: systemnyy metoda ta ekzystentsial'na ekspozytsiya [Strategic competitiveness management: systemic method and existential Exposition] - Mukachevo: Karpat·s'ka vezha. [in Ukrainian]

9. Miklovda, V.V., Kubiniy, N.Yu., Zavadyak, R.I. et al. (2010). Stratehichne upravlinnya efektyvnistyu pidpryyemstv u korporatyvnomu sektori rehionu: problemy ta shlyakhy vdoskonalennya [Strategic management of the enterprises efficiency in the regional corporate sector: problems and ways of improvement] - Uzhhorod: Lira [in Ukrainian]

10. Fedulova, L.I. (2005). Aktual'ni problemy menedzhmentu v krayini [Actual problems of management in the country]. - K.: Feniks [in Ukrainian]

Одержано: 12.09 .2018 p. 